Vol. 2, No. 2, 2020

Piotr Hadrian, Oksana Stets

Cracow university of economics

Lviv Polytechnic National University

\title{
THE POSSIBILITIES OF USING AUDIT AS A TOOL OF MARKETING CONTROL: THE CASE OF A POLISH AND UKRAINIAN COMPANY
}

$\underline{\text { http://doi.org/ }}$

(C) Hadrian Piotr, Stets Oksana, 2020

The article focuses on the issue of marketing control. The immediate goal is to show, on the example of analyzed cases of enterprises, real possibilities of using a marketing audit as a tool of strategic control of marketing. As a starting point for the considerations, the author quotes the views discussed in the literature on marketing audit (which may be viewed as conceptual, structural and process models) as well as the internal audit. The provided examples of good practice in the use of audit in marketing operations control included the research done in a Polish (Grupa Azoty SA) and a Ukrainian (Pryvatne aktsionerne tovarystvo Ternopilskyy molokozavod) company.

Key words: tools, audit, marketing, methods, marketing control

\section{Introduction}

An efficient system of control is estimated to be one of the guarantees of rentability of management activities undertaken in the case of every function of an organization, including marketing. Control indicates the areas of marketing of different levels of usage, effectiveness and efficiency, thus marking the need for changes in the terms of allocation of resources, connection between different activities, changes of scope and intensity of activities, becoming one of the essential factors influencing the level of efficiency of the marketing management system. It incites to become interested in the methodology of marketing control, in the theoretical as well as pragmatic concept.

The need for, and the importance of strategic control, stressed in the considerations on marketing, prompted the authors to commence research on the practical application of a marketing audit, a distinguished tool at that level of control. The main objective of the presentation is to show the potential use of good practice in the use of marketing control on the example of two researched companies, Grupa Azoty SA і ПрАТ Тернопільський молокозавод. The research is based on the theoretical concepts of using audit in marketing control, which may be treated as model approach (although the propositions offered by the authors weren't presented as models in a direct manner). For the fulfilment of the intermediate goal the method of a systematic review of publications in the scientific bases of Scopus, Web of Science and Ebsco has been used. ${ }^{1}$ The final goal was achieved thanks to the research carried out by the case study method.

${ }^{1}$ The overview was made by conducting a selection of publications placed in the bases analyzed, containing phrases marketing control, marketing audit. From selected set on the basis of the abstract review and texts of the accessible papers a narrowing has been introduced, limiting only to these, which in a forward manner discussed the issues of the prevalent importance to the author that is presenting a semantic, conceptual, structural or process approach to the audit seen as a marketing control tool. Simultanously the authors referencing also to the texts not recognised in the penetrated bases.. 


\section{Audit as a tool for strategic marketing control}

Relatively little space is devoted to the issues of control in literature, which takes a comprehensive look at marketing or management. Its be the consequence of a view, that the measurement of marketing effects involves complex problems of marketing activity assessment which, despite the general theoretical knowledge about both control methodology as well as marketing proves very difficult, if not impossible to specify. This means that also the definition of theoretical basis of marketing control seems difficult, not to mention its practical implementation. Marketing is a market activity in which numerous cause and effect relationships are quite complex and difficult to isolate. Many relationships can be described in qualitative, and not quantitative categories. The researched phenomena are frequently elusive, random, dynamic, while control mechanisms are imperfect (declarative, intuitive). Due to the foregoing, the definition of theoretical basis of marketing control seems difficult, let alone its practical implementation.

Marketing control is frequently divided into operational and strategic areas. ${ }^{2}$ Operational control is in most cases related to the operational plan of marketing (usually one-year). Hence, it concerns the assessment of such activities within the assumed short timeframe, in keeping with the provisions, in order to reach the set goals. Strategic control embracing all the adopted provisions (directions, forecasts, adopted policies for marketing operations) that is the basis for an update or elaboration of a new marketing strategy for a company, should follow the systematic operational marketing control. In one of the descriptions of the marketing control structure, the strategic level includes: an assessment of marketing accuracy, an assessment of marketing excellence, a marketing audit ${ }^{3}$, a review of ethical and social responsibility of the company [6, p. 683]. Marketing audit is understood as a complex, systematic, independent, regular and professional examination of the marketing environment as well as of the objectives, strategies and the activity of an entity (a company, SBU, institution). The examination is conducted to identify the correct implementation of strategic marketing decisions. A marketing audit is one of the tools designed for the evaluation and improvement of the use of marketing in company's operations.

The idea of a marketing audit emerged in marketing literature at the cusp of the 1950s and 1960s. With the use of the management consultants' experience, audit technique was introduced to the marketing practice, and the researchers began to analyze the value that might be derived by streamlining marketing operations due to reaping the results of such an audit [7]. Scientific considerations about marketing audit were initiated by the publication of American Management Association of 1959 [8]. The starting point for its considerations was the perception of a marketing audit as a tool fulfilling not only a forecasting function, but also a diagnostic one. That tool might by applied by both well-prospering companies as well as those coping with serious market difficulties attributable to objective market threats, weaknesses of organizations, or their inability to play their strengths or opportunities emerging in the environment [9].

The audit procedures were deemed to be prerequisite owing to the necessary lasting market reorientation of organizations. By that token, an audit was to be perceived as a certain standard, a recurrent analytical and control procedure, implemented in the inherently inter-related stages that decide about the end- result. Marketing audit stages that were distinguished at that time included setting a goal, deciding on a detailed program of an audit and organizing operations prerequisite for the program implementation [10]. That suggestion may be assumed to be the first procedural model of an audit, which the next author enhanced with a structural form by adding six basic elements of a marketing activity subject to evaluation: goals, strategies, organizational system, methods, procedures and personnel [11]. Two types of a marketing audit were distinguished to substantiate the need for comprehensive audits. The types of an audit were identified from the angle of the scope of activities covered by the assessment which defined the level of detail of the assessment: a horizontal, comprehensive audit and a vertical audit of a partial nature [12].

Investigations into the area of a marketing audit that were reflected by the subsequent publications, despite their insights into interesting issues of an audit (e.g. the issue of its characteristic features, the

\footnotetext{
${ }^{2}$ Other marketing control structure proposals distinguish a larger number of its components [1-4].

${ }^{3}$ Some authors express a different view, situating the audit in the area of marketing analysis [5].
} 
possibilities for its use, its strategic character [13], differentiation in terms of the scope and the forms of implementation [14], technical implementation of an audit [15]) did not bring any new solutions which could be then treated as audit models. In the late 1960s, a conviction that companies reach for a marketing audit in the act of despair, in a critical situation when grappling with real problems, became dominant. For these reasons, the audits conducted usually took the form of a limited marketing control (activity-level audit) or evaluation of very detailed activities, focusing on grappling with the symptoms of an unfavorable situation rather than on the fundamental problems.

Early in the 1970s, an earlier suggestion was confirmed by the literature which said the scope of a marketing audit should cover all marketing activity, due to mutual relationships between its functions and instruments. Thus, a model solution was proposed both in terms of conceptual as well as process aspects, which suggested an audit including a review of marketing environment of an organization which would evaluate the efforts made by a company to understand its environment, marketing system whose purpose is a complex assessment of the internal marketing system and specific marketing elements (issues) diagnosed in the first two stages of the procedure [16].

In the 1970s of the need to use an audit as one of the key control tools in the management process began to infuse managers' minds. This tool was so interesting and valuable that further attempts were made to define its structure. One of them indicates a marketing audit model (a process approach) with three distinctive stages: definition of the goals and scope of an audit, collection of the empirical material, and preparation and presentation of the results [17]. The presented audit process may be treated as a simplistic model of a "black box" whose stages were described without a thorough consideration of the input and output elements, and the mechanisms taking place within the process.

The distinction of six basic components of a marketing audit, i.e. audit of the company's environment (broken down into a macro- and micro-environment), a marketing strategy, organization of marketing operations, a marketing system, the efficiency of marketing operations and operationalization $[17]^{4}$ should be considered an important achievement of the researchers of a marketing audit of that time. The proposal can be perceived to be a structural model of the scope of a marketing audit. That model highlights the logic of that control tool, i.e. commencing the research with the assessment of the market situation of a company and the changes taking place on the market, the ensuing threats and opportunities, then the examination of company's marketing goals and the related strategies, organizational, systemic and financial issues, and ultimately a more thorough examination of one, or a few of them that may exert a major impact on the efficiency and effectiveness of marketing.

Late in the 1970s, the considerations of theoreticians and practitioners' opinions confirmed the value of an audit attributable to the fact that it focuses on the main provisions of marketing activity. For that reason, it was considered to be the main element of marketing strategic control [20]. The author put forward solutions that would simplify the process and standardize the scope of an audit, aiming at making it more accessible and approachable to companies [21]. H.W. Goetsch [22] formulated a similar proposal comprising research questions to 13 issues which are the subject of an audit. ${ }^{5}$ However, the opinions about practical application of that research and development potential were ambivalent, much weaker than the importance attributed to an audit [23, 24].

In keeping with the research on the practical aspects of an audit application, A. Wilson [25] suggested an original structural solution comprising a set of 28 issues addressed by an audit, adding lists of corresponding control questions. Some of the identified issues were the newly perceived areas of evaluation, yet most of them resulted from the refinement of marketing issues that require control, previously identified by the researchers. However, that proposal might be regarded as another structural model of a marketing audit giving more precision and depth to the potential scope of auditor's considerations.

4 At that time, some other proposals were put forward to set out crucial areas of a broadly understood marketing audit, such as a 15-element proposal by McConnel [18], and 7-element structures by Naylor and Wood [19], and McDonald [18], supplemented with extensive lists of audit questions.

${ }^{5}$ Those proposals that treated an audit as an analytical tool in the process of planning marketing activity, were an extension of the views already presented in the 1960 s. 
In the 1980s, an audit began to be perceived as an efficient tool in modifying the existing, or introducing a new perception of the marketing concept in an organization, a guide for the decision makers, introducing them to the strategic role of marketing and stimulating the decision making process. As a process with three distinctive stages: a diagnosis of the existing and historic marketing context of a company, a forecast of a company's dynamics that would consider the anticipated changes in market conditions, a formulation of a set of recommendations preceding the planning process, aimed at improving the directions and efficiency of marketing [26]. The audit understood in this way provided the assessment of the crucial strategic elements of a company. At the same time, it was considered a universal methodological procedure that allowed the implementation of the four roles (hierarchically ordered in line with the awareness of a company of the marketing concept and its implementation practice). The roles were described as a communication tool, analytical scheme, decision making catalyst and an element of directional policy. Mokwa's marketing audit concept fully implements the features of the model in conceptual, process and structural terms.

In the 1990s, attempts were made to develop the audit methodology by suggesting new solutions in the area of its implementation, with the focus on separate control areas and the research questions assigned to them [27, 28]. In the following decades, other detailed models of the structure of a marketing audit, containing various sets of the audited issues, were elaborated on the basis of those, and earlier morphological proposals. L. Tvede and P. Ohnemus [29] distinguished eleven research problems, and Copernicus consulting company pointed to twenty one general areas of marketing operations [30]. The basic merit of the above model structural proposals consists in the definition of the control components and lists of research questions for a marketing audit to give direction to its implementation. Each of those proposals (at the level of a general specification of issues) may be considered to be a model structural solution, yet of just one element of an audit structure, i.e. the scope.

Finally, the audit concepts described in the literature, which can be considered as model solutions for marketing audit, are presented in Table 1.

Table 1

\section{Concept (model) of marketing audit}

\begin{tabular}{|l|l|}
\hline \multicolumn{1}{|c|}{ Autor } & \multicolumn{1}{|c|}{ The essence of the described marketing audit concepts } \\
\hline 1 & \multicolumn{1}{|c|}{2} \\
\hline A. Shuchman & $\begin{array}{l}\text { "Systematic, critical, impartial analysis and evaluation of all marketing activities, i.e. basic goals } \\
\text { and principles (policy) of operation, assumptions on which they are based, methods, procedures, } \\
\text { personnel and organizational structure used in implementing this policy and achieving goals" [9, } \\
\text { p. 16] - semantic model }\end{array}$ \\
\hline R. Sessions & $\begin{array}{l}\text { Setting a goal for the improvement in a company's market position over a certain period of time } \\
\rightarrow \text { deciding on a detailed program of an audit drafted in terms of time and events, and designed } \\
\text { so that to reach the assumed objectives } \rightarrow \text { organizing operations prerequisite for the program } \\
\text { implementation (in terms of chronology and subjects) [10] - procedural model }\end{array}$ \\
\hline A. Oxenfeldt & $\begin{array}{l}\text { Six basic aspects of the marketing activities to undergo evaluation: objectives, strategies, } \\
\text { organizational system, methods, proceedures and staff [11] - structural model }\end{array}$ \\
\hline E.A. Tirmann & $\begin{array}{l}\text { Marketing audit including: } \\
1 . \quad \text { marketing environment of an organization which would evaluate the efforts made by a } \\
\text { company to understand its environment; it should include an assessment of the state of market } \\
\text { intelligence, competitive situation, consumer profile, structures and commercial practice } \rightarrow \\
\text { 2. a marketing system whose purpose is a complex assessment of the internal marketing } \\
\text { system, i.e. the structure and the content of goals, programme provisions and their } \\
\text { implementation, and the organization of marketing } \rightarrow \\
\text { 3. specific marketing elements (issues) diagnosed in the first two stages of the procedure } \\
{[16]-\text { conceptual/procedural model }}\end{array}$ \\
\hline Ph. Kotler & $\begin{array}{l}\text { "Marketing audit is a periodic (repeatable), comprehensive, systematic and independent study of } \\
\text { the organization's marketing environment, its internal marketing system (goals, strategies) and } \\
\text { individual activities" [14, p. 376] - semantic model }\end{array}$ \\
\hline
\end{tabular}


The possibilities of using audit as a tool of marketing control: the case of a polish and ukrainian company

Cont. table 1

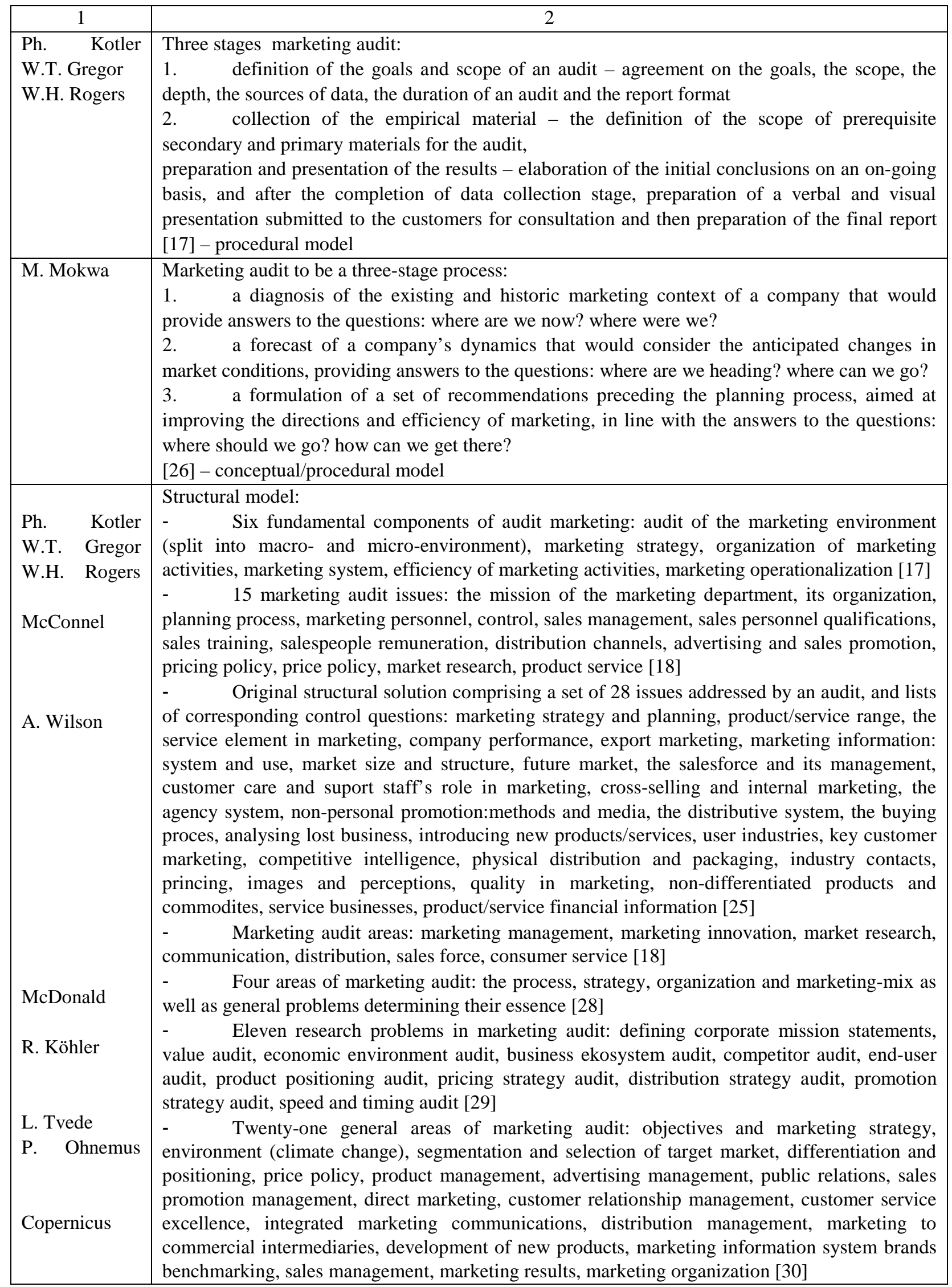

Source: own elaboration. 
The above proposals provide a general conceptual, structural or procedural basis, significant from the theoretical and methodical point of view as well as from the angle of application. Nonetheless, to this day, the opinions about practical application of marketing audit has ambivalent, and marketing audit has not reached the level of methodological unambiguity.

The practice of marketing, as reflected by the results of a marketing audit research (in a broader sense - a control of marketing activity) does not indicate a high degree of a marketing audit use. The results of the research that was conducted, and then described in the marketing literature, poised to evaluate the use of a marketing audit show, irrespective of the tested market, the type of tested entities, the time and methodology of research, that audit has not been perceived as a significant tool of marketing strategic control, and the extent of its use is negligible [23, 31-40]. The observed methods of using an audit to investigate marketing issues do not originate from the expectations, decisions or activities of organizational units directly responsible for marketing. They also do not have a clear strategic inclination, and are frequently satisfied with the correctness assessment at the operational level. This calls into question the legitimacy of treating these controls as an audit (in theoretical terms) which has been prescribed a strategic dimension of the assessment.

Therefore, it is important to study the level of its use of this marketing control tool in practice. Irrespective of the concept or the form of an audit, it is important to reach for this tool in line with the view that strategic control concludes each management process. It is to be expected that such approach will be directly reflected in the practice of marketing activities.

The results of the research conducted and described in the marketing literature to assess the use of marketing audit indicate (regardless of the market studied, the type of surveyed entities, time and methodology of the study) that the audit is not perceived as an important tool of strategic marketing control, and the degree of its use is very limited.

\section{Good examples of a marketing audit implementation}

The objective of the research done within 2016 - 2017 was to verify the opinions on the degree of use of audit to control the operation of enterprises [40]. It was resolved to conduct qualitative research with the application of case research of an explanatory, classical and multiple character. The analysis and description of a few cases of enterprises allowed assuming the degree, depth and methodology of good practice in the strategic control of marketing activity, with the use of a marketing audit. The appropriate material for research was collected by way of personal, in-depth interviews with the managers of the researched companies as well as by direct scrutiny of the documentation of a marketing audit.

Study population included prospering companies whose mother companies were seated in southern Poland. Owing to the contacts maintained within the framework of the co-operation between the CUE Department of Marketing and the foreign centers, permission was granted to conduct research in the companies in the Czech Republic, the Slovak Republic and Ukraine. The research program allowed finding companies operating on the Polish and Ukrainian markets (Grupa Azoty, ПрАТ Тернопільський молокозавод), for whom an audit became an important tool of marketing control. Those companies make perfect examples of good practice of a marketing audit.

Grupa Azoty S.A. is an entity that has a few decades of market experience by engaging in manufacturing, providing services and trading in chemical industry. Grupa Azoty S.A. is a dominant player of a capital group, and it has been listed at WSE (Warsaw Stock Exchange) ${ }^{6}$. The company has been consistently implementing the provisions of its many year development strategy, and developing its potential by taking over other entities on the market. The group has been co-operating with the research and scientific institutes, providing services within laboratory research, technical consulting, thus allowing optimal choice and use of the properties of plastics.

${ }^{6}$. The accomplished technical, market and social achievements that had been gained through the long years of functioning of that entity were skillfully discounted in the past few decades, providing a good example of maintaining continuity of operation in turbulent changes of political and economic situation. 
Due to the highest quality of products as well as stable business contacts, the company has enjoyed a strong, sustained position on the Polish and international market. The company has been upholding sustainable development principles, improving proprietary technologies for environmental protection and elimination of the threats attributable to their activity and the products delivered to the market. A high position of the company, both on the domestic as well as international markets, has been attested by numerous prestigious awards and distinctions.

Between 2001 and 2015, within the framework of audits done by an internal audit unit especially appointed in the structure of the researched company, there were 149 audits. In this number, 29 were directly, or indirectly connected with the marketing activity of the company ${ }^{7}$. They were typical vertical audits, focused on the selected, very concrete marketing issues, which included:

- activities (costs, results) taken to win new customers;

- the efficiency of promotional activity;

- management and the use of the expense and advertising accounts;

- correctness of reporting, opinion giving, keeping deadlines, and evaluation of the efficiency of research and design activity;

- correctness of the application of procedures pertaining to the claims made by the customers;

- price setting process for the chosen products;

- process to ensure the efficiency of control of the chosen finished products;

- logistic processes involved in the distribution of the chosen products, e.g. proper storage;

- designing and launching new products on the market;

- compliance with the principles of customer service;

- compliance with the principles and conditions of sale of the chosen products, to the chosen groups of contractors;

- the reasons for, and the prevention of stockpiling;

- profitability of sales of the chosen products;

- collecting, storing and circulating information about the trading partners and the company environment;

- verification of expenditure on strategic marketing, promotion and PR.

There are strong indications that the audits have been treated as a strategic control tool, used for such purposes as commissioning external audits conducted by entities independent from the audited unit; conducting audits by a specialized unit (professionalism); independent procedures that can check and verify the designated units, procedures, or documents (objectivism); the importance of issues chosen for the audit of its units, the company, or the whole capital group (importance). All the same, the analysis of information about the audited periods raises some doubt as to their strategic importance. Once we assume that the strategic perspective should span a few years, then among the audited periods, seven concerned at least two years, nine one year, and the remaining much shorter time.

Most frequently, the successive audits were prompted by the doubts expressed by the members of the Board or the Supervisory Board. Each time, the audits were executed by a team of auditors appointed for the occasion. The teams included at least two external auditors, at least one representative of the marketing unit responsible for the audited operation, and at least one member of the middle or high management level directly involved in the audited area. The submitted documentation allowed tracing the

${ }^{7}$ An indirect relationship between the object of the research and marketing activity is apparent in the audit of processes designed for the efficient quality control of finished products, the audit of R\&D activity, the audit of outlays on design, implementation and registration of new inventions. Each audit directly involved the issues related to the technological process or financial settlements, and it was conducted by the organizational units held responsible for those spheres of activity. From the indirect perspective, there were clear relationships between the selected objects of control and purely marketing issues such as designing new products, care for high quality of the market offer, or minimizing the cost of production. 
whole procedure, including the results indicated by the auditors (jointly with the results of the optional secondary audits).

Audit reports signal the methodology of audit, provide summaries for the management (approach to the control, specification of risk involved in each investigated issue, synthetic results of control conclusions and recommendations), detailed results of control (observations, cause - effect relationships) and the necessary formal documents.

Identification of the types of risk involved in certain areas, is an important element of the audit procedure. To give an example, one of the audits indicated a risk involving a loss of a part of the market due to the insufficient reaction to the competition, implementation of the obsolete work, and consequently generating unnecessary costs or outlays, exclusion of important development work in the approved development plans, thus incurring extraordinary losses due to the loss of the potential revenues. Awareness and definition of the consequences of errors and imperfections that may, or do appear as a result of the activity in the examined area, seem to be an important element that gives direction and mobilizes for an audit.

In the documentation of marketing audits in the examined enterprise, the most common methods of examination included scrutiny of the source documentation (regulations, accounting documents, logistics contracts, contracts, procedures, reports and analyses), observations made by the members of the audit team, in-depth interviews with the managers and staff. Consequently, in the result of the foregoing, audit teams had sufficient material at their disposal that allowed making qualitative (and less frequently, also quantitative) analyses, and then giving appropriate recommendations.

In the predominant part of audit documentation, in case there were discrepancies found between the desired condition, expected from the formal point of view, and the actual state, recommendations suggested adjusting operations to the formal and legal requirements. Nonetheless, the recommendations included also quite pragmatic conclusions. One of the conclusions said that the implemented solutions were more efficient than those dictated by current internal regulations. Consequently, it was recommended to elaborate such new formal procedure that would be consistent with the conducted operations, and then make it obligatory in the new updated regulations.

The source documentation submitted by the company (each audit is registered and filed as full documentation, showing the successive steps of an audit procedure) proves the professional conduct of audit activities. The key factor prerequisite for the implementation of ordered audit procedures was the awareness of the job as well as professional preparation of the staff of the Internal Audit Department.

From the perspective of theoretical features of that control tool, the major drawback of the audit conducted in that company is the fact that it was not comprehensive. It was easy to note that control was quite narrowly profiled, which in practice did not allow evaluating the whole area of marketing operations of the company. The assessment of the use of some tools, if not derivative forms thereof, or of a narrow area does not provide answers to the rudimentary question, which is: to what degree is the marketing strategy consistent with the challenges of market reality?

Tarnopol Milk Processing Plant was the second audited entity. It is one of the largest dairy sector companies in Ukraine, which has been delivering products to the Ukrainian consumers for almost 20 years. The company was established as a new entity on the basis of a plant founded in 1956. In 1999, a new cadre of managers took control, restructuring the company, and rebranding it as ЗАT Тернопільський молокозавод. In the organizational terms as well as in terms of the technical infrastructure, the company was built from scratch. At the beginning, the company was divided into, and operated along three basic functions, on a modest budget: production, administration and finance. Once it became more efficient and reached better results that were accepted by the shareholders, the company expanded its operation in human resources management, $\mathrm{R} \& \mathrm{D}$, innovation and marketing.

Initially, the company was serving the local market of Tarnopol and its surroundings. In time, it extended its operations to the adjacent markets (concentric strategy) as well as initiating activity in other regions of the country (island strategy). The company operates without the intermediaries in deliveries and 
supplying the wholesale market. It controls all stages of its production and the commercial cycle; from the collection of milk from the dairy farmers, to delivery to the retail outlets. In 2014, the company was granted ISO and HACAP certificates, which required the adoption of certain obligations and procedures. The plant ranks among five largest producers in Ukraine. Owing to the investment in technology and organization (14 subsidiaries, in the Western Ukraine and Kiev, Chernihof and Odessa) as well as in marketing, the company became the leader in Western Ukraine. The company adopted a different selective strategy in Eastern Ukraine, and consequently it puts it in the beginning of the second ten in milk production in that region ${ }^{8}$.

In targeting individual consumers by its marketing activity (B2C), the plant launched Молокія brand 9 . The plant was the first in Ukraine, and fifth in Europe to launch Fresh Milk Technology assuring highest quality of products and bringing them as much as possible to natural cow milk. The company has been also operating on B2B market producing casein and butter. Their products are traded under ПрАТ Тернопільський молокозавод brand name on the Ukrainian market and also exported (Israel, the Middle East, Asiatic countries).

The company started its marketing activity along with its restructuring in 2000 . As we can see in the structural chart, Trade and Marketing Department is listed in the Sales section, yet it is separate from the Sales Management Department. The scope of marketing section activity includes marketing research, market segmentation and positioning, implementation of product innovations, creation of new products in response to the expectations of the target market, creation and development of brands. The gradually introduced marketing activities were controlled through the on-going supervision (both current as well as follow-up) and at the final stage (conclusion or a re-start), to assess their efficiency and effectiveness. Such control proceeded along two formalized processes: the current control spanning one-month periods of marketing, and the annual control checking the implementation of the plan.

HACAP and ISO certificates granted in 2014 entailed the obligation to carry out certain procedures. Those included an obligatory audit of the functions implemented by the company. In compliance with this requirement, the company set up the Internal Audit Section which reported directly to the President of the Board. Audit procedure has been described in the internal document on planning and internal audits ${ }^{10}$, which is a part of "The system for ensuring quality and safety of food products" (ISO 22000, ISO/TS 22002-1 $)^{11}$. The document describes an audit as a set of systematic, independent, documented and objective activities that comply with the requirements prescribed for such control. The document specifies the dates, terms and categories related to an audit, the tasks of the head and the audit team members, audit procedure, source documents and the structure of working documents used in the course of an audit.

Auditing procedures mainly pertain to the duties of higher level managers, as they have been entrusted with carrying out audits and the implementation of the resultant recommendations. This emphasizes the strategic nature of such control, which is of great importance for the understanding of the audit. The audit covers all structural units which are engaged in production processes, and have any impact on the quality and safety of products as well as all the processes related to ensuring quality and safety of food products (beginning with the administrative processes, and ending on formal and production ones). The regulations enforced by the Plant envisage an obligation of an annual audit of marketing, yet sales department is audited every six months. Such a timetable for audits raises serious doubts as to their strategic character.

The Chief Auditor reports directly (and solely) to the President of the Board. To implement the scheduled audits, the auditor sets up individual task teams ${ }^{12}$. The teams group only the managers who are

\footnotetext{
${ }^{8}$ A relatively small share in the market is attributable to the specialization of the company in the production of hard cheese, melted cheese, ice cream, or dry dairy products.

${ }^{9}$ The brand was registered in 2007.

${ }^{10}$ The document specifies the stipulations of the regulation published by the Ministry of Ukrainian Economy [41].

11 Certificates were granted by the international office for certification, BUREAU VERITAS.

12 Pursuant to the document, the chief auditor may not set up a team, but he has to conduct the audit by himself. Once the team has been set up, the chief auditor must act in the capacity of a team leader.
} 
the professionals in their functional areas. Such solution should reduce (prevent) all kinds of informal connections which may bear on the process and the obtained results of an audit. In case of a marketing audit, the team of auditors usually includes the chief auditor (the top-down approach), the sales director ( the opposite-side audit), the financial director (the parallel audit), and the staff member responsible for the safety of operations pursuant to ISO standards.

In case of a repeated control, aimed to evaluate the processes of implementation of post-control recommendations, the audit team should include only the members of the Internal Audit unit. Marketing Director, as the person in charge of the audited unit, shall not be a member of the auditing team ${ }^{13}$. Nonetheless, he should be involved in the audit in operational terms (the activities of various stages of the audit), similarly to other staff members of the marketing department, who should provide the necessary information, prepare and submit the necessary documents, analyses, etc.

It is also possible to involve the external auditors ${ }^{14}$, who must meet certain criteria, i.e. they must be conversant with the auditing procedures and the industry. Under certain circumstances, it is possible to commission a fully independent, external audit initiated by the marketing director. In this case, the objective of the audit would be ascertaining the correctness of the implemented tasks. Such option was not employed during the analyzed audit ${ }^{15}$.

Every time, an audit commences with the definition of the scope, the objective, and the subject, and the formulation of the list of issues that should find answers. The list is the aftermath of cyclical meetings of the board, the supervisory board and high level managers, and it specifies the issues that raise concern or misunderstandings, and which should be subject to discussion during the successive functional audits. Within the timeframe 2015 - 2017, not many questions were asked which is to say, not many marketing audit issues were identified.

Within the audits, control focused primarily on innovative products (market and marketing surveys, creation of new products, mostly assortment goods, and not their categories or lines, positioning products on the market, building, promotion and brand enhancement). Focusing marketing audits around the processes of product creation seems most reasonable, as a product is a crucial element of companies' marketing activity. On the other hand, it demonstrated a strong connection between the marketing area of the company and R\&D.

Audits always focus on two rudimentary dimensions: financial aspects (Has the budget been properly set? Have the financial resources been spent properly? Was it possible to cut the costs?), and procedural aspects (has the decision making process and operations complied with the binding regulations and procedures?). High level company managers (financial and sales directors) focus on the substantive layer of the audited decisions and operations, while other internal auditors (chief auditor and ISO expert) concentrate on controlling the procedures, so that the company qualifies for certification of various areas of its operations.

An audit concludes with a report, which is submitted to all persons it may concern (the Board, Supervisory Board, higher level managers). However, it is not customary (let alone prescribed by the procedure), to hold a meeting in which the auditors would present the results of the audit to the above mentioned persons. Hence, there is no opportunity for a deeper analysis, interpretation or a discussion on the results, conclusions and recommendations.

In the opinion of business practitioners and scholars, any form of control (including audits) arouses anxiety among the Ukrainians, and is perceived in a negative way. Control leads to distancing, both to the auditor and his activity. However, the on-going generational change in the audited company (particularly at

\footnotetext{
${ }^{13}$ In case of an audit of sales, he must be a member of the team of auditors.

${ }^{14}$ It is possible to commission a fully independent, external audit initiated by the marketing director, poised to confirm the regularity of the implemented tasks.

${ }^{15}$ The Board of the company did not support such solution, pointing out to a high risk of a wrong evaluation attributable to the fact that the potential auditors were not familiar with the industry or local conditions. There were also some difficulties in finding the suitable (acceptable) auditors that would meet the prescribed criteria.
} 
the managerial level), and the advent of young people not encumbered with the negative experience of control, who have a broader perspective of that managerial activity, cause that the staff are more and more open towards control. They stop perceiving control as a supervisory tool ultimately aimed at imposing individual penalties, but start to see it as an instrument for shaping organizational culture intended for reaching a better result of the functioning of the organization as a whole.

From the formal angle, the marketing audits conducted in the company should be considered as fully professional. Nonetheless, it would be difficult to evaluate their content since the audit documentation was not made available. Beyond any doubt, the issues that were considered suggest a vertical audit, conducted by the task teams set up in compliance with the procedure. The controlled activities were rather tactical than strategic, and the issues were not directly referred to marketing strategies.

\section{Conclusions}

The presented two companies show the possibility for a practical application of an audit in the function of a marketing tool. The companies operate in various industries, on various markets (B2C, B2B) and in various geographical regions, in various reality of economic management (Poland and the EU, Ukraine). The common denominator of these entities is their size and the scale of operation. Both companies fall into the category of large entities, regardless of the criteria for such classification. This gives some potential, also in the area of control.

In marketing terms, both companies proceeded with an audit in line with the stipulations of an internal audit rather than the concepts described by the theory of marketing. In conclusion, those examples of audit implication to the control of marketing do not display any strong connections with the methodological concepts (models) of a marketing audit, as described in the literature. While the subject of the audits - mostly vertical in their nature - are legitimate marketing issues, their strategic character is very doubtful, both in terms of the time frame (the period under investigation) as well as the references to the strategic provisions of marketing.

On the final note, it may be asserted that the presented cases are examples of a good marketing audit practice, yet they are not free from fault - or at least they raise some methodological doubts. As it seems, it would be opportune to make audits more closely related to the methodology of an internal audit, in the area of considerations strictly connected with marketing control.

\section{References}

1. Baruk B. 2002.Nowoczesna strategia marketingowa. Aspekty strukturalne i procesowe. Warszawa: Wydawnictwo Naukowe PWN.

2. Haas R. W. 1996.Industrial marketing management. Boston: PWS-Kent Publishing Company.

3. McDonald M., \& Wilson H., 2012.Plany marketingowe. Warszawa: Oficyna a Wolters Kluwer business

4. Mruk H., 1999.Kontrola marketingowa. Podstawy marketingu (pp. 266-279). Poznań: Wydawnictwo Akademii Ekonomicznej w Poznaniu

5. Piercy N. , 2003.Marketing. Strategiczna reorientacja firmy. Warszawa: Wydawnictwo Felberg SJA

6. Kotler Ph. 1994.Marketing. Analiza, planowanie, wdrażanie i kontrola. Warszawa: Gebethner i Ska

7. Kotler, Ph. 1977. Marketing management. New York: Prentice Hall Inc.

8. Eds. Newgarden A., \& Bailey E. R. 1959.Analyzing and improving marketing performance: „Marketing audits" in theory and practice, AMA Management, Report No. 32. New York: American Management Associations.

9. Shuchman A. 1959.The marketing audit: Is nature, purposes and problems ed. Newgarden A., \& Bailey E. R. Analyzing and improving marketing performance: „Marketing audits” in theory and practice, AMA Management, Report No. 32. (pp. 11-19). New York: American Management Associations.

10. Sessions R. 1959. What a soundly conducted marketing audio can accomplish. ed. Newgarden A., \& Bailey E. R. Analyzing and improving marketing performance: „Marketing audits” in theory and practice, AMA Management, Report No. 32. (pp. 20-24). New York: American Management Associations

11. Oxenfeldt A. 1959. The marketing audio as a total evaluation program ed. Newgarden A., \& Bailey E. R. ed. Newgarden, A., \& Bailey, E. R. Analyzing and improving marketing performance: „Marketing audits” in theory and practice, AMA Management, Report No. 32. (pp. 25-36). New York: American Management Associations 


\section{Hadrian Piotr, Stets Oksana}

12. Crisp R. 1959. Auditing the functional elements of a marketing operation ed. Newgarden, A. \& Bailey E. R. ed. Newgarden A., \& Bailey E. R. Analyzing and improving marketing performance: „Marketing audits” in theory and practice, AMA Management, Report No. 32. (pp. 37-46). New York: American Management Associations

13. Oxenfeldt A. 1966. Executive action in marketing. Belmont: Wadswoth Publishing

14. Kotler Ph. 1967. Marketing management: Analysis, planning, and control, Upper Saddle River: Prentice-Hall

15. Rothman F. Intensive Competitive Marketing Journal of Marketing, 1964. 28(3), 10-17. doi: $10.1177 / 002224296402800303$

16. Tirmann E. A. Should your marketing be audited, European Business, 1971. Autumn, 49-56.

17. Kotler Ph., Gregor W. T., \& Rodgers W. H. The marketing audit comes of age, Sloan Management Review, 1977. 18(Winter), 25-43.

18. Da Gama A. P. Marketing audits: The forgotten side of management? Journal of Targeting, Measurement and Analysis for Marketing. 2012. 20(느), 212-222. doi: 10.1057/jt.2012.17

19. Naylor J., Wood A. 1978. Practical marketing audits: A guide to increased profitability. New York: John Wiley \& Sons,

20. Enis B. M., \& Mokwa M. P. 1979.The marketing management matrix: a taxonomy form strategy comprehension. eds. Ferrell, O. C, Brown, S. W., \& Lamb Jr., Ch. W. Conceptual and theoretical developments in marketing. (pp. 485-505). New York: American Management Associations,

21. Wilson M. T. 1980.The Management of Marketing, Westmead: Gower Publishing Company Ltd.

22. Goetsch H. W. Conduct a omprehensive marketing audit to improve marketing planning Marketing

News. 1983. 18 March, Section 2, 14.

23. Capella L. M., \& Sekely W. S. The marketing audit: methods, problems and perspectives Akron Business and Economic Review. 1978. 9(3), 37-41.

24. Myers J.G., Massy W.F., \& Greyser S.A. 1980.Marketing research and knowledge development, Englewood Cliffs: Prentice-Hal,

25. Wilson A. 1982. Aubrey Wilson's marketing audit check lists: A guide to effective marketing resource realization, New York: McGraw-Hill

26. Mokwa M. The strategic marketing audit: An adoption/utilization perspective // Journal of Business Strategy. 1986. 6 (4), 88-95. doi: 10.1108/eb039136

27. Brownlie D. The marketing audit: A metrology of explanation // Marketing Intelligence and Planning. 1993. 11(1), 4-12. doi: 10.1108/02634509310024128

28. Köhler R. 1993. Beiträge zum Marketing-Management. Stuttgart: Schaffer, Poeschel Verlag

29. Tvede L., \& Ohnemus P. 2001. Marketing strategies for the New Economy, Chichester: John Wiley

30. Kotler Ph. 2006. Kotler o marketingu. Jak tworzyć, zdobywać i dominować na rynkach. Gliwice: Wydawnictwo Helion

31. Taghian M., \& Shaw R. N. 2002. The marketing audit and business performance: An empirical study of large Australian companies Australia and New Zealand Marketing Academy Conference (ANZMAC) Proceedings. (pp. 3151-3157). Retrieved from https://www.researchgate.net/publication/237428376 The Marketing Audit and Business Performance An Empirical Study of Large Australian Companies

32. Dryl W. 2010. Audyt marketingowy. Warszawa: CeDeWu,

33. Kowal W. 2010. Kontrola skuteczności marketingowej - problem zmienności interpretacji i pomiaru. Wrocław: Wydawnictwo Uniwersytetu Ekonomicznego we Wrocławiu,

34. Kowal W. Audyt marketingowy jako narzędzie kontroli marketingowej w świetle wyników badań polskich przedsiębiorstw Prace Naukowe Uniwersytetu Ekonomicznego we Wrocławiu. Nauki o zarządzaniu. Management sciences. 2011. 222, 107-130.

35. Kowal W. System kontroli marketingowej w świetle wyników badań polskich przedsiębiorstw Marketing i Rynek. 2013. 3, 17-24.

36. Paştiu C., \& Lazea R. Marketing audit in industrial companies in Romania Progress in Eeconomic Sciences. 2014. 1, 281-288. doi: 10.14595/PIES/01/022

37. Serbănică D., Radulescu V., \& Cruceru A.F. The role of marketing audit in evaluation sustainable marketing performance in Romanian organizations Amfiteatru Economic. 2015. 17(40), 1011-1021.

38. Saeed M. A. Y., Bekhet H. A., \& Dhar B. K. (2018). Influence of marketing strategy audit on organizational performance through innovation capability in the corporate sector of Muscat, Oman. International Journal of Business Management, 1(2), 40-55. 
The possibilities of using audit as a tool of marketing control: the case of a polish and ukrainian company

39. Bachnik K. 2018. Audyt marketingowy w małych i średnich przedsiębiorstwach ed. SkowronekMielczarek A. Audyt biznesowy w działalności małych i średnich przedsiębiorstw (pp. 109-138). Warszawa: Oficyna Wydawnicza SGH

40. Hadrian P. 2020. Audyt marketing - strategiczne narzędzie kontroli marketingu. Studium teoretycznometodyczne. Kraków: Wydawnictwo Uniwersytetu Ekonomicznego w Krakowie

41. Poryadok planuvannya i provedennya vnutrishnikh auditiv dokumentuvannya realizatsiji jikh rezultativ $\mathrm{u}$ derzhavnomu agentstvi Ukrajiny $\mathrm{z}$ upravlinnya zonoyu vidchuzhennya ta $\mathrm{v}$ ustanovakh, organizatsiyakh ta pidpriemstvakh, sistemi jogo upravlinnya [Procedure for planning and conducting internal audits, documenting, implementing their results in the State Agency of Ukraine for Exclusion Zone Management and in institutions, organizations and enterprises of its system] Retrieved from http://dazv.gov.ua/diyalnist/audytorskadiialnist/poryadok-planuvannya-i-provedennya-vnutrishnikh-auditiv-dokumentuvannya-realizatsiji-jikh-rezultativ-uderzhavnomu-agentstvi-ukrajini-z-upravlinnya-zonoyu-vidchuzhennya-ta-v-ustanovakh-organizatsiyakh-ta-

pidpriemstvakh-sistemi-jogo-upravlinnya.html (2018.11.12)).

П. Хадріан, О. Стець

Краківський економічний університет Національний університет "Львівська політехніка"

\section{МОЖЛИВОСТІ ВИКОРИСТАННЯ АУДИТУ ЯК ІНСТРУМЕНТУ МАРКЕТИНГОВОГО КОНТРОЛЮ: НА ПРИКЛАДІ ПОЛЬСЬКОГО ТА УКРАЇНСЬКОГО ПІДПРИЕМСТВ}

(C) Хадріан П., Стеи̧ь О. , 2020

Стаття присвячена питанням маркетингового контролю. Мета - показати на основі проаналізованих підприємств можливості фактичного використання маркетингового аудиту як інструменту стратегічного контролю маркетингу. В якості відправної точки для висновків було зроблено посилання на обговорення в літературі поглядів про маркетинговий аудит (їх можна розглядати як моделі концептуального, структурного або процесного характеру) та внутрішній аудит. Як приклад можливості належної практики використання аудиту в управлінні бізнесом маркетингова компанія описує діяльність, яка здійснюсться в Польщі (Grupa Azoty SA) та Україні (ПрАТ "Тернопільський молокозавод").

Дісва система контролю визнана одним із гарантів ефективності управлінських завдань, які виконуються як частина кожної функції в організації, в т.ч. маркетингової. Контроль маркетингу вказує на різний ступінь використання, ефективності і результативності, тим самим визначаючи необхідність розподілу ресурсів, підключення різних видів діяльності, змінюючи обсяг та інтенсивність діяльності, стаючи таким чином одним із ключових факторів, що визначають рівень ефективності управління маркетингом. Це викликає інтерес до цього питання як теоретично, так і практично.

Потреба та важливість, підкреслені в публікаціях по управлінню маркетингом, проведенню стратегічного контролю, спонукало авторів провести дослідження, присвячені використанню маркетингового аудиту на практиці - один із значних інструментів для цього рівень контролю. Основна мета дослідження - представити практику використання аудиту в маркетинговому контролі на прикладі двох компаній - Grupa Azoty SA та ПрАT "Тернопільський молокозавод". Дослідження базується на теоретичних концепціях використання аудиту маркетингу, який можна трактувати як модельний погляд (хоча безпосередньо, ці пропозиції їх автори не розглядали як моделі). Для того, щоб описати ці концепції, базувалися на методі систематичного аналізу наукових баз даних Scopus, Web of Science та Ebsco.

Ключові слова: інструменти, аудит, маркетинг, методи, контроль маркетингу 